\title{
29. ICHNOFABRICS IN EOCENE TO MAESTRICHTIAN SEDIMENTS FROM DEEP SEA DRILLING PROJECT SITE 605, OFF THE NEW JERSEY COAST ${ }^{1}$
}

\author{
Andreas Wetzel, Geologisch-Paläontologisches Institut der Universität, Tübingen ${ }^{2}$
}

\begin{abstract}
Ichnofabrics in the sediments drilled at Site 605 reflect environmental changes. Long-term changes allow the section to be differentiated into four units, and short-term fluctuations define cycles in the range of several decimeters. The composition of the ichnofabrics is controlled by the availability of nutrients within the sediment (reflecting productivity in the surface waters and the sedimentation rate) and by oxygen content within the respiration water (related to deepwater circulation patterns as well as to the organic carbon content of the sediment).
\end{abstract}

\section{INTRODUCTION}

Many studies of deep-sea environments relate biogenic structures to ecologic conditions (e.g., Ekdale, 1977; Ekdale et al., 1984; Wetzel, 1981, 1983a, b). In deep-sea sediments, trace fossils can provide valuable information on the paleoecology and geologic history of the benthic macrofauna. This is important in that most macrorganisms living in the deep-sea environment are not preserved in the body fossil record (Ekdale, 1977).

This study is based on observations of biogenic sedimentary structures in sediments drilled at Deep Sea Drilling Project Site 605, which is situated on the upper continental rise off New Jersey at about 2,200 m water depth (Fig. 1). The bottom of the hole was $816.7 \mathrm{~m}$ below the seafloor; the upper $154 \mathrm{~m}$ were washed, but rotary drilling recovered the lower $662 \mathrm{~m}$ of sediment. The sediments drilled at Site 605 are heavily bioturbated. The deposits were normally several times reworked by organisms; thus, the continuing response of the burrowing macrofauna to environmental changes is well preserved, allowing a reconstruction of past environments.

Five lithologic units were distinguished at Site 605: Unit I, $198 \mathrm{~m}$ of Pleistocene gray, silt-rich clay; Unit II, $153 \mathrm{~m}$ of lower to middle Eocene biosiliceous nannofossil chalk rich in radiolarians and diatoms; Unit III, $214 \mathrm{~m}$ of lower to middle Eocene greenish gray nannofossil limestone with varying amounts of foraminifers and calcified radiolarians; Unit IV, $176 \mathrm{~m}$ of Paleocene dark greenish gray clayey nannofossil marls and limestones; and Unit V, $77 \mathrm{~m}$ of lower Paleocene to Maestrichtian olive gray, clayey limestone. An unconformity occurs between the upper Eocene and Pliocene.

Throughout the drilled section, carbonate content is usually greater than $60 \%$. The organic carbon content varies between 0.1 and $0.6 \%$ (with a mean of $0.22 \%$ ). The (compacted) sedimentation rates vary from 2 to 4 $\mathrm{cm} / 10^{3}$ yr. for Units III, IV, and V, whereas Unit II has

\footnotetext{
${ }^{1}$ van Hinte, J. E., Wise, S. W., Jr., et al., Init. Repts. DSDP, 93: Washington (U.S. Govt. Printing Office).

2Address: Geologisch-Palăontologisches Institut der Universităt, Sigwartstraße 10, D 7400 Tübingen, Federal Republic of Germany.
}

a markedly higher rate with an average of more than 10 $\mathrm{cm} / 10^{3}$ yr.

The Paleogene section shows evidence of cyclic sedimentation, especially in Units III and IV. An unusually high biosiliceous productivity began during the Eocene Epoch (Units II and III), reaching a constant high level in Unit II.

\section{METHODS}

Biogenic structures were identified by means of typical cross-sections. Because such identifications may be subjective, the trace fossils were defined only at the ichnogenus level (Häntzschel, 1965, 1975). Sometimes a subdivision of one ichnogenus was possible when distinct maxima in diameter distribution and differences in sediment infill were found (Wetzel, 1981).

In general, two types of biogenic sedimentary structures can be distinguished: (1) trace fossils with a well-defined shape and sharp and distinct outlines and (2) biodeformational structures, which have indistinct outlines and features and which destroy preexisting structures.

This study is based on visual observations of wet cores. This is important to note, because other methods of observation, for example, X-ray radiography (Wetzel, 1981), wetting with oil (Bromley, 1981), or staining (Risk and Szczuczko, 1977), allow the recognition of more types of trace fossils but fewer biodeformational structures.

As an additional complication, diagenesis may enhance certain burrow types, whereas others are more or less masked.

In this description only trace fossils are discussed. In Hole 605 sediments, trace fossils at and near the sediment surface had no chance of being preserved in the fossil record; hence, only more deeply burrowed traces are considered.

\section{RESULTS}

\section{Description of Trace Fossils}

\section{Chondrites}

Chondrites are three-dimensional burrow systems which normally branch downward into the sediment at angles of $30-60^{\circ}$. They are simple tunnels or wall-lined tubes (Wetzel, 1981) that consist of (1) a connection from the seafloor to (2) a typically branched lower part. In general, tunnels or tubes become more horizontal with depth below the surface of the seafloor (Fig. 2). Different types were identified in the sediments drilled at Site 605 by their differing diameter and sediment fill, as suggested by Wetzel $(1979,1981)$. Chondrites in Hole 605 also had reworked other burrows (= composite burrows; Fig. 3). 


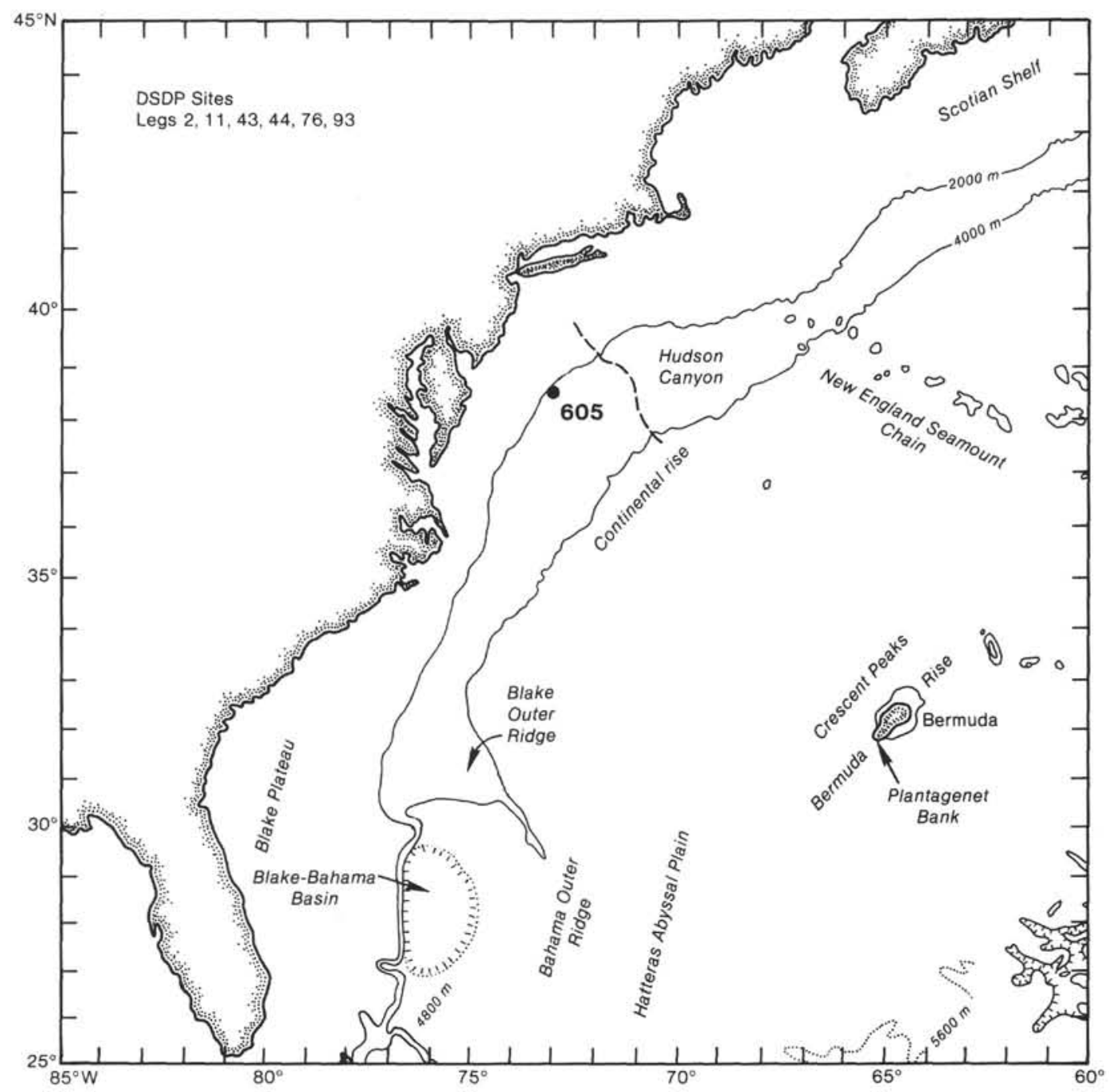

Figure 1. Location of Site 605.

\section{Cylindrichnus}

Cylindrichnus is composed of a series of tapering, subconical, concentric sheaths consisting of alternating fine-grained and coarse-grained material (Figs. 2, 3).

\section{Helminthopsis (sensu Chamberlain, 1975)}

This ichnogenus is an irregular, curved, tangled tube system with several short "dead ends." The tube diameter is about $1 \mathrm{~mm}$. In the Hole 605 sediments, Helminthopsis is found only in association with other burrows (= composite burrows).

\section{Planolites}

Planolites, which frequently occurs in the Site 605 sediments, is normally unbranched, straight or gently curved, cylindrical, and more or less horizontal. Active filling of the burrow is indicated by (1) grain-size differences with the surrounding sediment and (2) relatively close packing of infill. The latter point was deduced from the fact that no differential compaction occurs between Planolites and other stuffed burrows (e.g., Chondrites). This was proven by the method described by Einsele and Mosebach (1955) and by Crimes (1975): originally circular cross sections of biogenic tubes or tunnels (cut perpendicularly to their axis) become deformed to ellipses by compaction, with the deformation corresponding to the degree of compaction. However, in a compacting sequence such geometrical differences of burrows are very subtle and can be detected only by accurate observations (Wetzel, unpublished data).

The structure of the backfilled sediment is not typical, but these burrows were nevertheless grouped into the ichnogenus Planolites - in contrast to Pemberton and Frey (1982), who postulated a typical fill structure-because the active fill itself is thought to be a major criterion, whereas the formation of a fill structure may be subordinate. The active fill of these burrows determines that they cannot belong to the category of Paleophycos traces that have been filled in a passive and structureless fashion.

\section{Skolithos}

Skolithos is a simple, vertical shaft of a uniform diameter, varying between 2 and $15 \mathrm{~mm}$ (Fig. 2). 


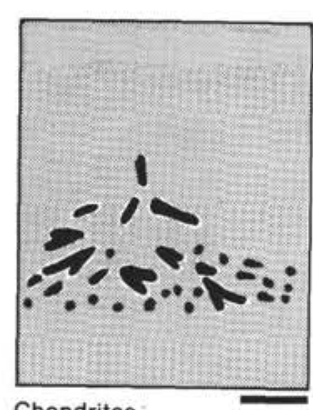

Chondrites
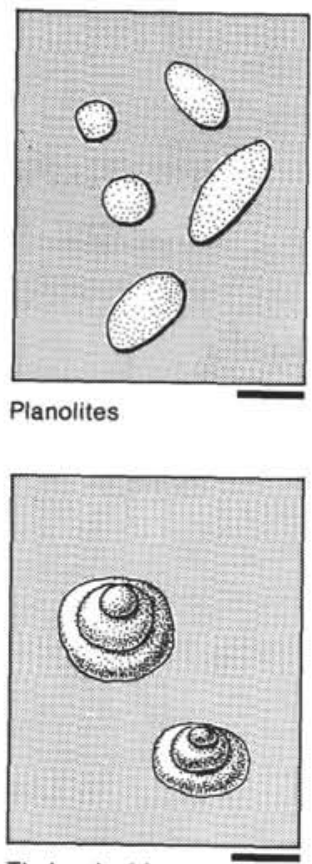

Thalassionides

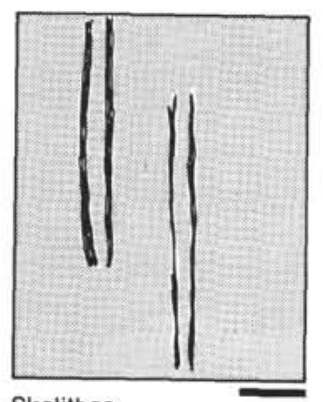

Skolithos
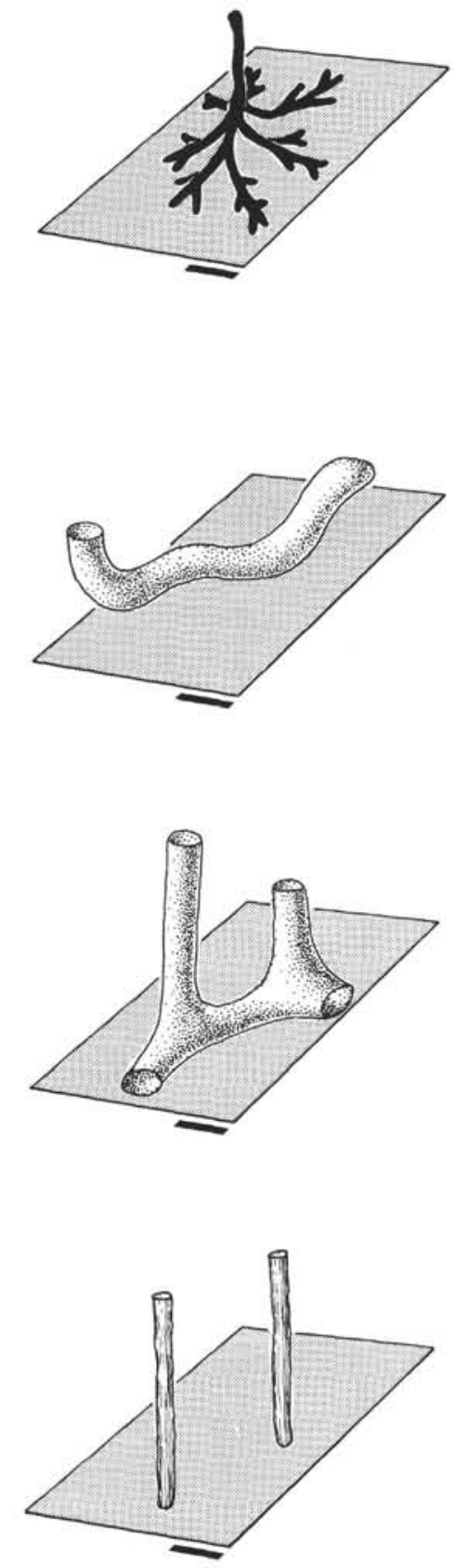

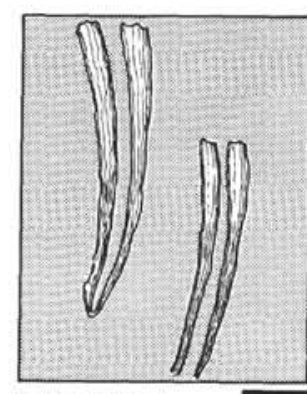

Cylindrichnus

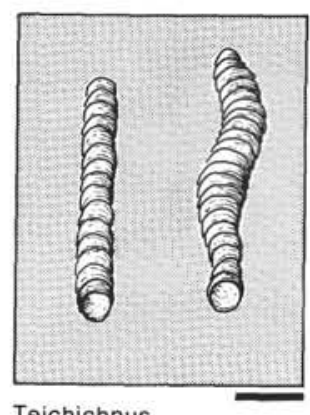

Teichichnus
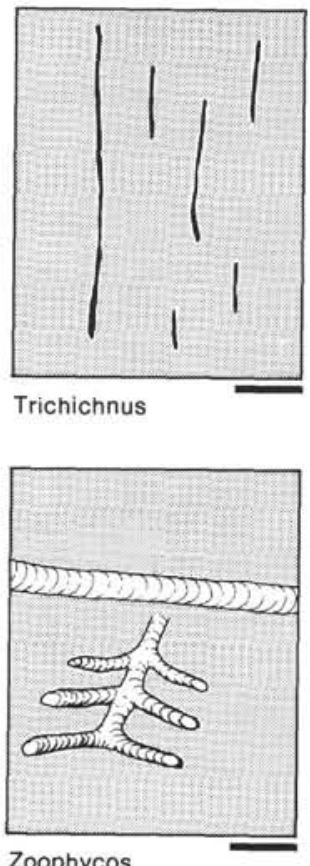
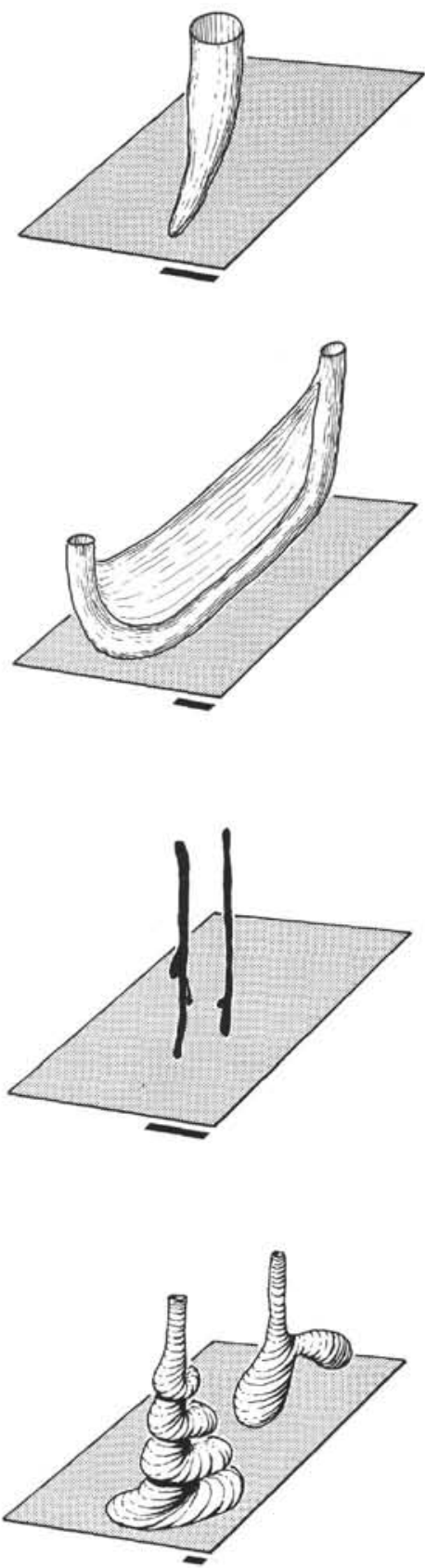

Figure 2. Schematic drawings of the commonly occurring trace fossils. Scale bars $=1 \mathrm{~cm}$.

\section{Teichichnus}

This trace fossil is a spreiten-burrow, formed by the vertical (upward or downward) shift of a flat tunnel. Its configuration resembles stacked roof gutters with a tunnel on top (or bottom) (Figs. 2, 3).

\section{Thalassinoides}

Thalassinoides is composed of cylindrical tubes that branch to form a three-dimensional, more or less horizontal network connected to the seafloor surface by sub- vertical or vertical shafts. Typical swellings at the bases of branches or elsewhere are observed (Fig. 2). A typical asymmetrical (eccentric) fill structure (Fig. 3) often results from active filling by the burrowing organism or collapse of the burrow walls. The tubes are $5-20 \mathrm{~mm}$ in diameter. Two size-categories can be distinguished, with approximately $5 \mathrm{~mm}$ and about $15-20 \mathrm{~mm}$ diameters.

\section{Trichichnus}

Trichichnus is a threadlike, rarely branching, cylindrical burrow, more or less vertical, up to $20 \mathrm{~cm}$ in length, 

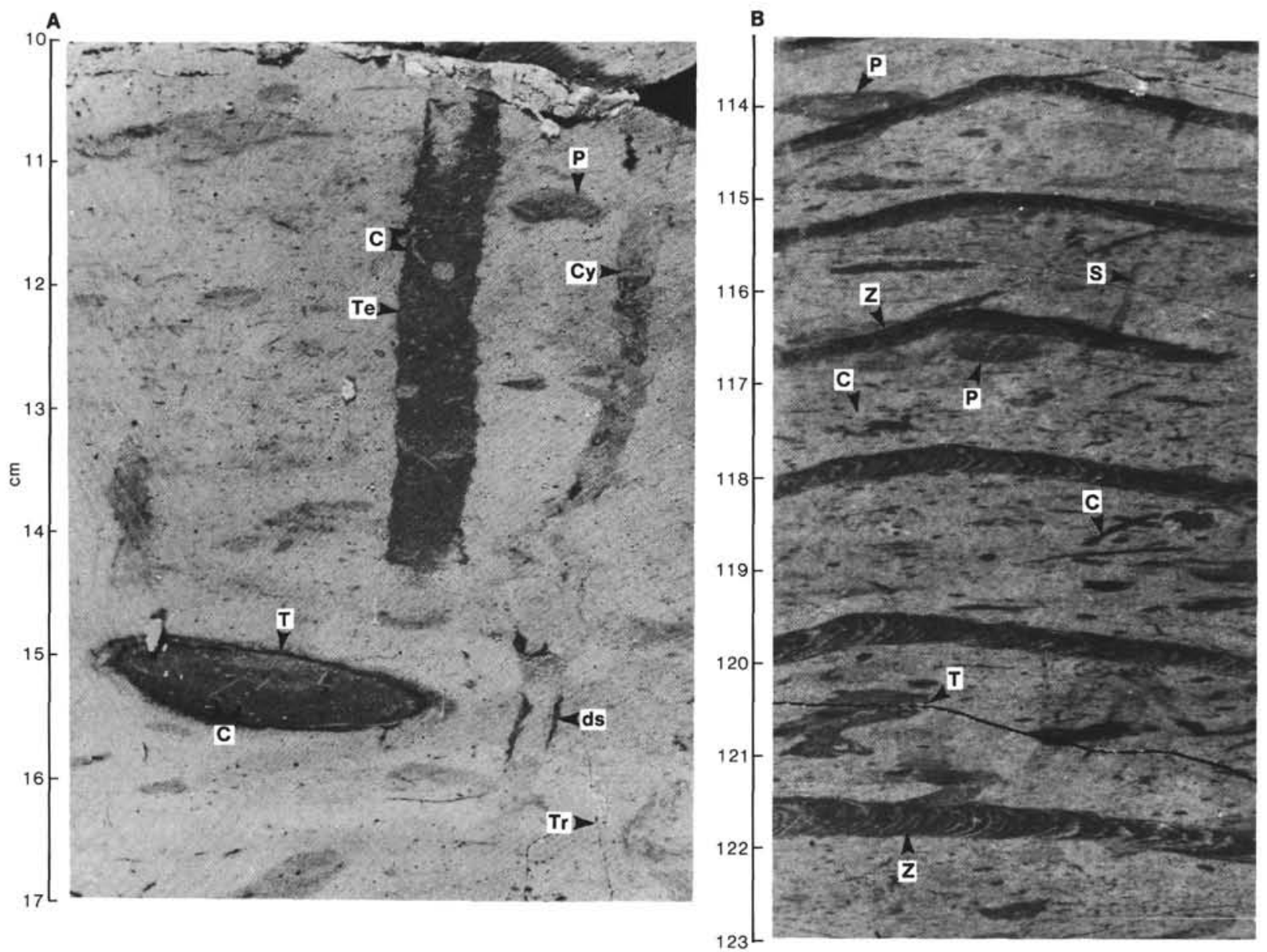

Figure 3. Example of the commonly occurring trace fossils. A. Sample $605-16-4,10-17 \mathrm{~cm}$. B. Sample $605-57-1,111.3-123 \mathrm{~cm}$. C = Chondrites (in A as composite burrow); $\mathrm{Cy}=$ Cylindrichnus; $\mathrm{ds}=$ diagenetically stained part of Cylindrichnus; $\mathrm{P}=\mathrm{Planolites;} \mathrm{T}$ $=$ Thalassinoides; $\mathrm{Te}=$ Teichichnus; $\mathrm{Tr}=$ Trichichnus; $\mathrm{S}=$ Skolithos; and $\mathrm{Z}=$ Zoophycos.

and $0.1-1.0 \mathrm{~mm}$ in diameter (Fig. 2). In Site 605 sediments Trichichnus is normally filled with pyrite (Frey, 1970; Fig. 3).

\section{Zoophycos}

Zoophycos are composed of horizontal to oblique feeding spreiten which surround the nearly vertical part in distinct levels or spirals (Figs. 2, 4). In cross sections the spreiten often exhibit regular, crescentic structures (Fig. 3 ). The spreiten vary in thickness from 1 to $10 \mathrm{~mm}$ (Fig. 4). Zoophycos-producing organisms can burrow several decimeters deep (Wetzel and Werner, 1981). Zoophycos can have an open (U-type) or stuffed (J-type) marginal tube indicating, respectively, a lower or higher oxygen content in the respiration water (Wetzel and Werner, 1981).

\section{Diagenetically Stained Burrows}

Throughout the section drilled at Site 605, there are burrows which are totally or partially "stained" by diagenetic processes, either by precipitation or leaching. Such diagenetic effects apparently occur in burrows or parts of burrows which formerly were lined with organic material and had an open connection to the seafloor. This may favor the formation of a strong chemical gradient within the sediment. However, these burrows show various degrees of diagenetic staining that are probably due to differences in sediment composition (i.e., in grain size or organic-matter content).

Many different burrows are enhanced by diagenesis, including:

1. Chrondrites. This burrow sometimes shows darkly stained infilled sediment. Chrondrites burrows found close together show differences in staining, suggesting that they may differ in their organic lining. It is possible that different types of Chondrites can be distinguished by this criterion, but this study did not do so.

2. Planolites. Stained Planolites burrows are often referred to in the literature as halo, rind, or solid burrows depending on the amount and area affected by leaching or precipitation caused by diagenesis (e.g., Chamberlain, 1975; Ekdale, 1977) (Fig. 4).

3. Thalassinoides. The walls of this burrow are preferentially enhanced by chemical diagenesis, although the staining may also exceed the boundary of walls (Fig. 3).

4. Zoophycos. Some Zoophycos specimens show a differentiated staining (Fig. 4). This starts in the vertical part of the burrow, which has the most lining and a longterm exposure to circulating respiration water, being used throughout the life of the Zoophycos organism. The feeding spreiten surrounding the vertical part are less clearly stained because they are exploited only for short periods (Wetzel and Werner, 1981). Furthermore, diagenetic stain- 

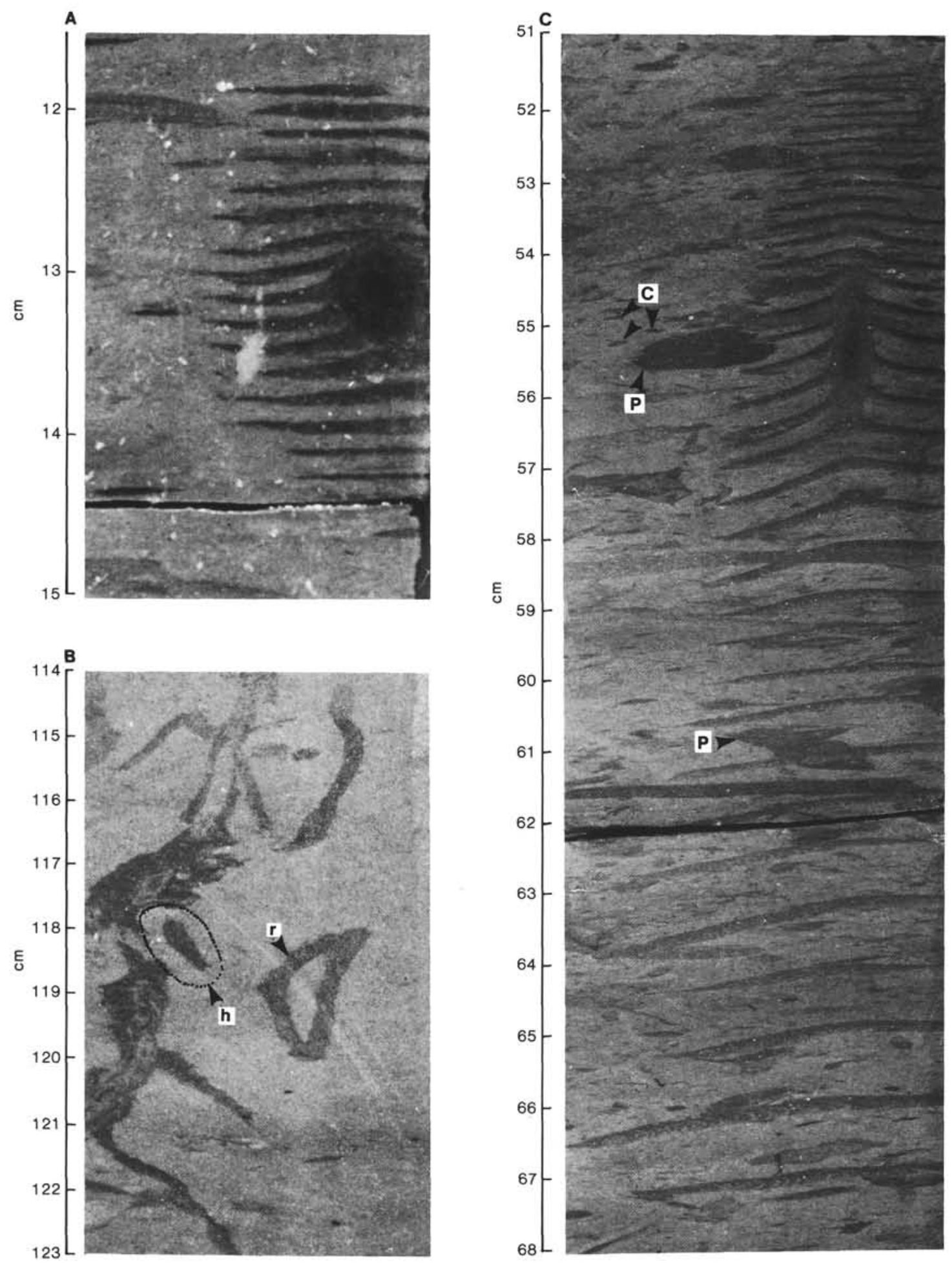

$68 \mathrm{~L}$

Figure 4. Various types of Zoophycos occurring in the Site 605 sediments. A. Sample $605-45-1,11.5-15 \mathrm{~cm}$; very small specimen. B. Sample 605-62-3, 114-123 cm; Zoophycos with vertically extended central part. Note diagenetic staining, rind burrow (r), and halo burrow (h), in which the halo has partially discolored Zoophycos. C. Sample 605-52-2, 51-68 $\mathrm{cm}$. Large Zoophycos with 36 whorls around the central part. Note that Zoophycos penetrates other previously emplaced traces: Planolites $(\mathrm{P})$ and Chondrites $(\mathrm{C})$, which also penetrates Planolites. 
ing progresses from the burrow wall into the surrounding sediment (Fig. 3).

It is still an open question why all of the burrows in these categories do not show diagenetic staining and why often only parts of them are stained (compare Figs. 3, 5, 7 with Figs. 9, 10, 11). This may be due to abrupt, but probably initially small, changes in chemical and physical conditions within the sediment.

\section{Factors Influencing the Interpretation of Ichnofabrics}

In interpreting biogenic structures, it is important to take into account how deeply a trace-producing organism burrowed within the sediment. The penetration depth can affect the documentation of benthic life in mainly two ways: (1) The deeper an animal burrows, the higher is the preservational potential of the resulting trace (Werner and Wetzel, 1982). (2) The preserved biogenic structure obviously resides in sediment which is older than the burrow itself. The time difference between "apparent" and "real" burrowing activity $(d t)$ can be formulated by the equation

$$
d t\left(10^{3} \mathrm{yr} .\right)=\frac{\text { penetration depth }(\mathrm{cm})}{\text { sedimentation rate }\left(\mathrm{cm} / 10^{3} \mathrm{yr} .\right)}
$$

Because compaction affects "apparent" penetration depth and sedimentation rate in the same way, a correction for "decompaction" is not required.

An animal's depth of burrowing can be estimated in two ways:

1. The relative penetration depth of an organism is determined by the position of a trace fossil within the sequence of intersecting biogenic structures; the shallower a burrow within the seafloor, the larger is the number of different trace fossil types penetrating it. In the Site 605 sediments the following succession can be deduced, from shallow to deep burrowing: Planolites-Teichichnus-Thalassinoides-Chondrites-Zoophycos (Fig. 5).

2. The absolute depth of burrowing can be estimated by observing the displacement of particles from marked layers. These values need to be corrected for compaction (see earlier description of Planolites); otherwise, estimation of the burrowing depth can be influenced by the degree of compaction. As shown in Figure 6, the penetration depth of Zoophycos-producing organism can thus be estimated as $30-40 \mathrm{~cm}$.

\section{Classification and Interpretation of Ichnofabrics}

The varying nature of the ichnofabrics allows the cored sediment to be subdivided into several units. Because these unit boundaries nearly coincide with those between the lithologic units defined aboard ship, the ichnofabric units, were numbered so as to correspond to the numbered lithologic units. Therefore, ichnofabric Unit I (uncored Pleistocene section) is missing.

\section{Ichnofabric Unit II (Cores 7 to 22)}

The following trace fossils frequently occur: Chondrites, Cylindrichnus, Planolites, Skolithos, Teichichnus, Thalassinoides, Trichichnus, and Zoophycos. Unit II is characterized by abundant trace fossils and few biode-

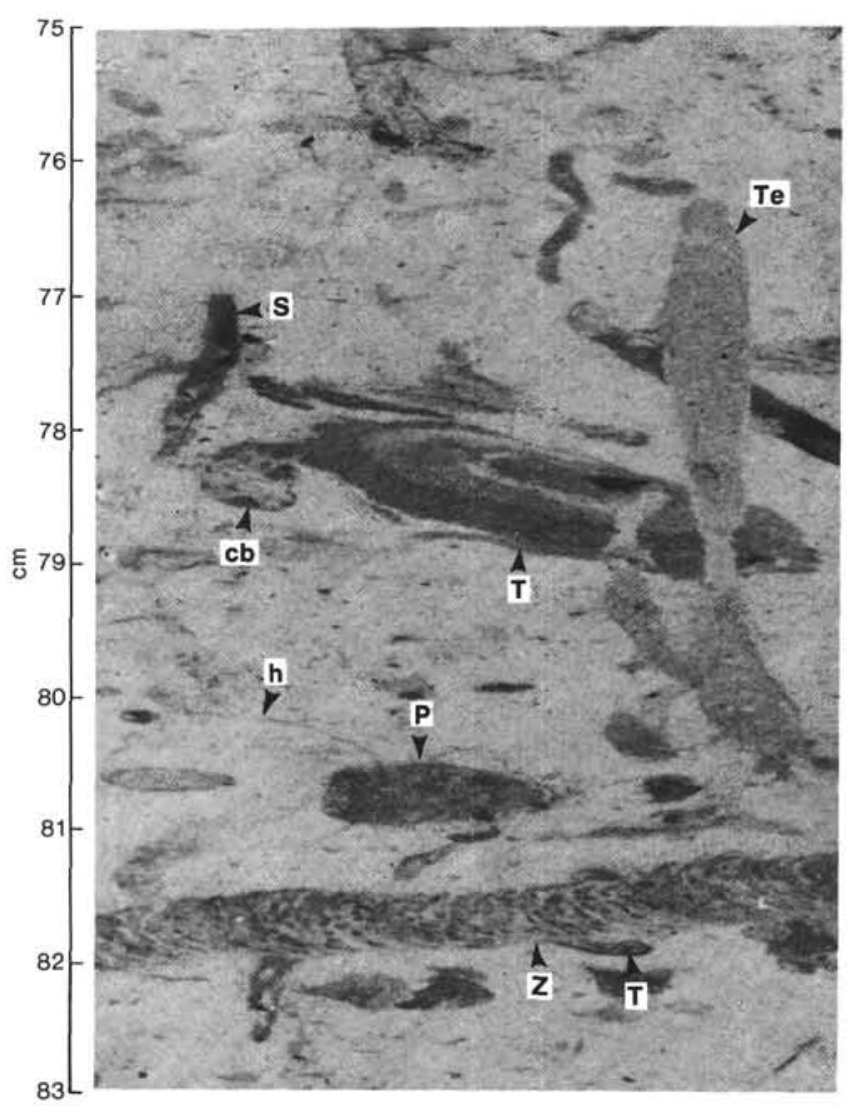

Figure 5. Intersecting trace fossils indicating different burrowing depth of endobenthic organisms, Sample 605-21-1, 75-83 cm. Zoophy$\cos (\mathrm{Z})$ penetrates all other burrows, Teichichnus $(\mathrm{Te})$ intersects Thalassinoides (T) (but see Fig. 7) that crosses Planolites (P). Planolites penetrates Skolithos (S). Chondrites (cb) sometimes reworks other burrows, forming composite burrows; h marks the outer boundary of a halo around a Planolites burrow.

formational structures. Compared to the other units, Teichichnus and Thalassinoides burrows are considerably more frequent (Figs. 3A, 5, 7).

The nature of the ichnocoenosis can be related to environmental conditions when compared with modern continental margin sediments. Modern deposits off northwest Africa contain a similar assemblage of trace fossils, and the relationship between biogenic structures and the environmental setting is known (Wetzel, 1979, 1981, 1983a).

1. In Unit II, a high proportion of vertically extended burrows with an open connection to the seafloor (Chondrites, Teichichnus, Thalassinoides, and occasionally Cylindrichnus and Skolithos) indicate more rapid sedimentation than in the other units. These burrows also indicate also a high burial rate of organic matter (nutrients) that is governed by the high sediment accumulation rate (Müller and Suess, 1979). Such conditions might have led to oxygen depletion within the sediment, a possibility indicated by the frequently occurring burrows of the types just mentioned as well as Zoophycos with unstuffed marginal tube (Wetzel and Werner, 1981).

2. The nature of the Unit II ichnocoenosis reveals cyclic changes in the environment. The cycle length varies 


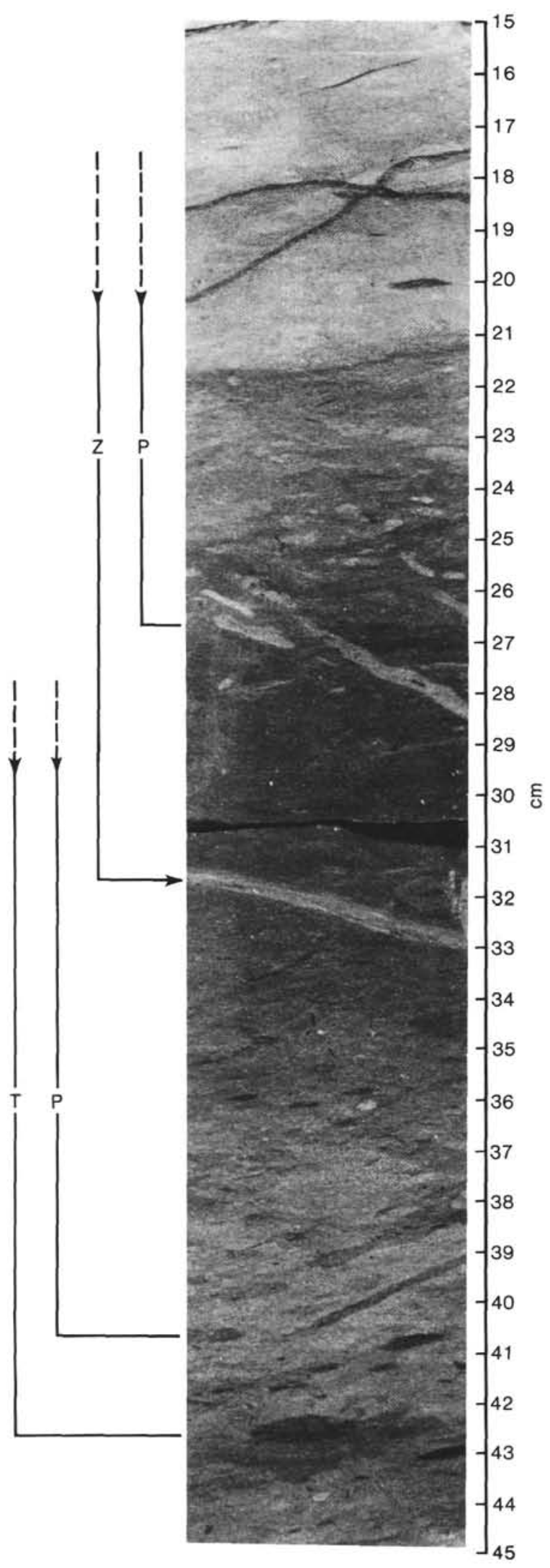

Figure 6. Vertical displacement of particles indicates burrowing depth of trace-producing organisms. Sample $605-44-3,15-45 \mathrm{~cm} . \mathrm{P}=$ Planolites, $5-10 \mathrm{~cm}$; $\mathrm{T}=$ Thalassinoides, $8-12 \mathrm{~cm} ; \mathrm{Z}=$ Zoophy$\cos , 10-15 \mathrm{~cm}$. Corrected for compaction, these values may be 1.5 to 2.5 times higher.

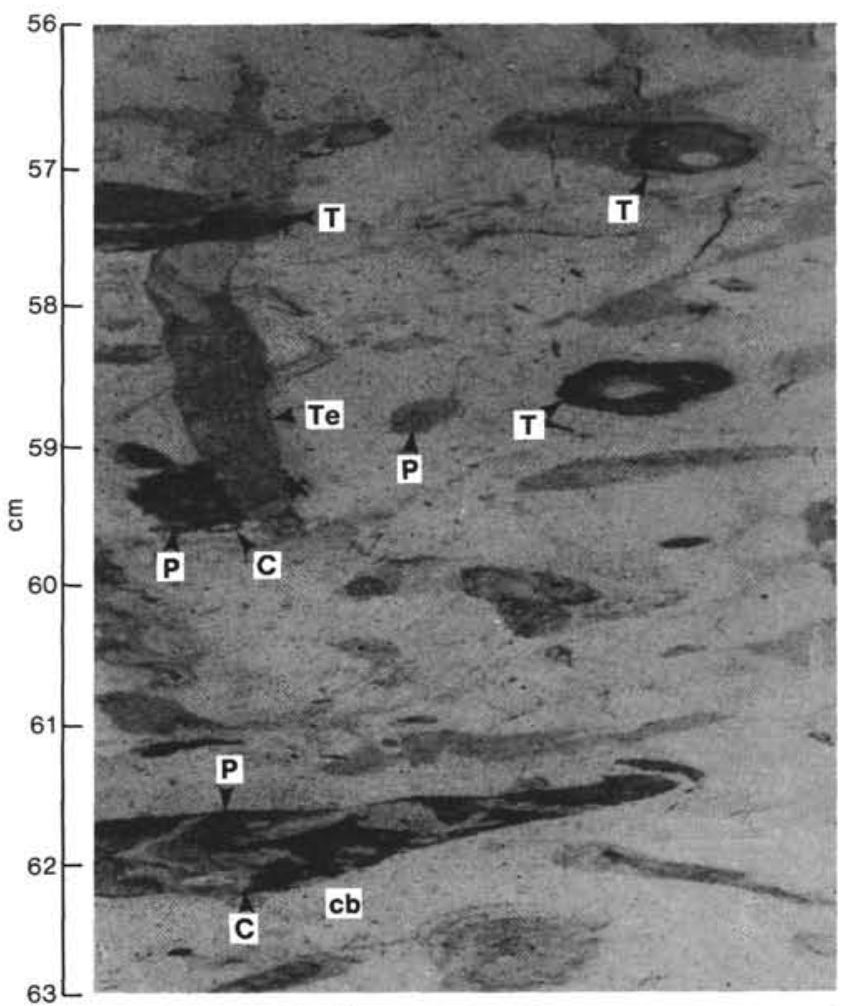

Figure 7. Typical example of ichnofabric Unit II (see also Figs. 3A and 5). Sample 605-17-1, 56-63 cm. C = Chondrites, $\mathrm{cb}=$ composite burrow type of Chondrites, $\mathrm{P}=$ Planolites, $\mathrm{T}=$ Thalassinoides, $\mathrm{Te}=$ Teichichnus. In this photograph, different burrowing depth of endobenthic organisms can be deduced. In contrast to Figure 5, Thalassinoides $(\mathrm{T})$ here penetrates Teichichnus (Te). Because they mutually intersect, both burrows may be produced within a similar depth in sediment.

between 0.5 and $1.5 \mathrm{~m}$, the mean being $1.2-1.3 \mathrm{~m}$. Within a cycle from bottom to top, the frequency of vertically oriented burrows with an open connection to the seafloor increases, whereas the number of Planolites-like burrows decreases.

\section{Transition between Ichnofabric Units II and III (Cores 22 to 32 )}

The boundary between these two units is not sharply defined; rather, it forms a transition zone. Within this transition, ichnofaunal elements of Units II and III alternate cyclically. However, downcore (below Core 24) the ichnofaunal elements from Unit III predominate and the cycle length simultaneously decreases.

\section{Ichnofabric Unit III (Cores 32 to 43)}

This unit contains the following ichnogenera: Chondrites, (small) Planolites, Thalassinoides, and Zoophycos (Fig. 8). Planolites dominates, whereas Thalassinoides seldom occurs. In general, the faint color banding, laminations, and the high proportion of biodeformational structures (Fig. 8) indicate that biogenic reworking of the deposits is less intense than in Unit II. Using the observations of Wetzel $(1981,1983 a, b)$ in modern deepsea sediments, the trace fossils in Unit III can be interpreted as showing a lower sedimentation rate and burial rate of nutrients than in Unit II; also the lesser degree of 


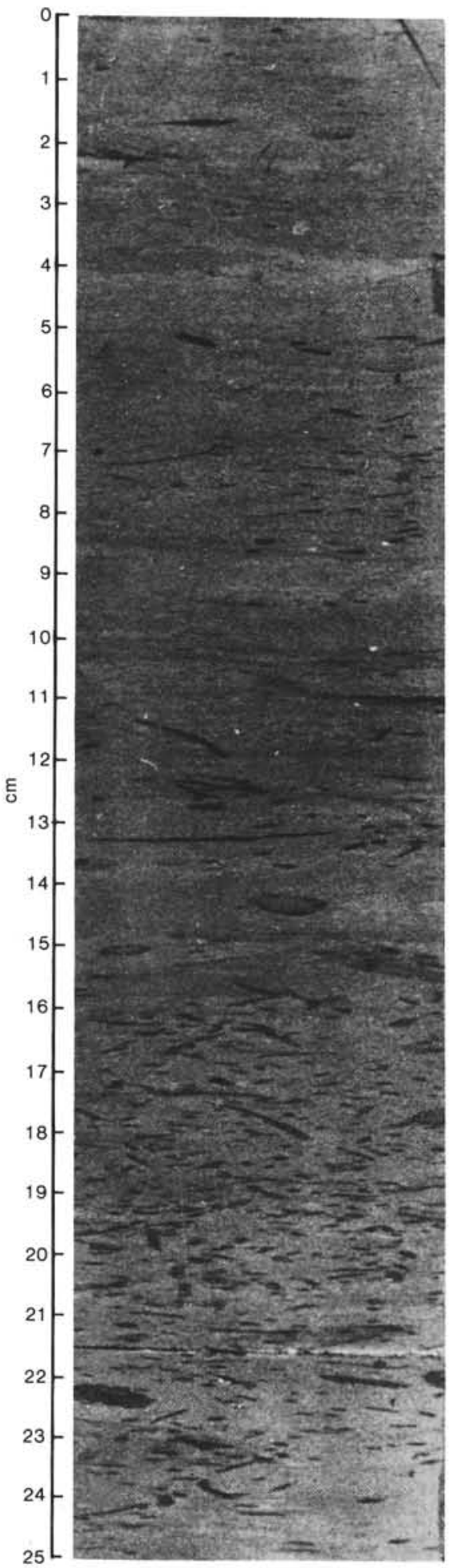

Figure 8. Typical example of ichnofabric Unit III. Sample 605-45-5, $1-25 \mathrm{~cm}$. Besides the homogeneous background (biodeformational structures), only Chondrites and Planolites burrows can be seen.

bioturbation in this unit suggests that somewhat less oxygen was available in the interstitial(?) respiration water.

Cyclic environmental fluctuations are documented in trace fossil diversity and in the proportion of trace fossils to biodeformational structures. The Unit III cycles are shorter than in Unit II-40-120 cm (a mean of 60 $80 \mathrm{~cm}$ ).

The transition between Units III and IV occurs within Cores 43 and 44.

\section{Ichnofabric Unit IV (Cores 44 to 60)}

The trace fossil diversity in this unit is comparatively high, but the intensity of burrowing is somewhat lower than in Unit II. The trace fossils found are Chondrites, Planolites, Thalassinoides, Zoophycos, and some Cylindrichnus (Figs. 5, 9).

Typical for this unit is the dominance of Zoophycos, particularly U-types. The small size of Zoophycos and the high frequency of U-types indicate less than optimal living conditions; perhaps there was an oxygen deficiency in the respiration water (Marintsch and Finks, 1978; Wetzel and Werner, 1981).

Cyclic environmental fluctuations, within the range of several decimeters, were also observed in this unit. Diversity varies significantly, as does the proportion of small-sized burrows and Zoophycos.

\section{Transition between Ichnofabric Unit IV and V (Cores 60 to 65)}

This transition is characterized by varying diversity and degree of bioturbation. Chondrites, Planolites, Thalassinoides, and Zoophycos are frequent. Additionally there are varying proportions of biodeformational structures (Fig. 10), which occur in cycles of between 0.4 and $0.8 \mathrm{~m}$ (mean about $0.5 \mathrm{~m}$ ).

Changes in the ichnofabric make it possible to subdivide the transition zone into three ichnofabric units.

In $\mathrm{A}$ (Cores 60 to 62 ), Zoophycos does not occur so frequently as in Unit IV, and the burial rate of nutrients appears to be lower.

B (Cores 62 and 63) is totally bioturbated, with a high diversity of fossils (Chondrites, Cylindrichnus, Planolites, Teichichnus, Thalassinoides, Trichichnus, and Zoophycos). The proportion of biodeformational structures is relatively low in comparison to the other sections of the transitional unit. In general, such an ichnofabric documents a nearly optimal use of the sediment by the endofaunal organisms because the habitat is fractionated into many ecological tiers. Such conditions are favored by (1) enough nutrients within the substrate for a high sedimentation rate to preserve nutrients even deeper in the sediment, and (2) anoxic conditions within the sediment, with an adequate supply of oxygen in the water at the seafloor.

C (Core 64) is dominated by the ichnogenus Planolites.

\section{Ichnofabric Unit V (Cores 65 to 71)}

The inventory of biogenic structures and the degree of bioturbation is similar to that of Unit IV: Chondrites, rare Thalassinoides, and Zoophycos, whose frequency decreased downcore. Furthermore, diagenetically stained burrows are common. The proportion of biodeformational structures and trace fossils varies within a considerably wide range. In some intervals a faint lamination, probably secondary, can be observed. 

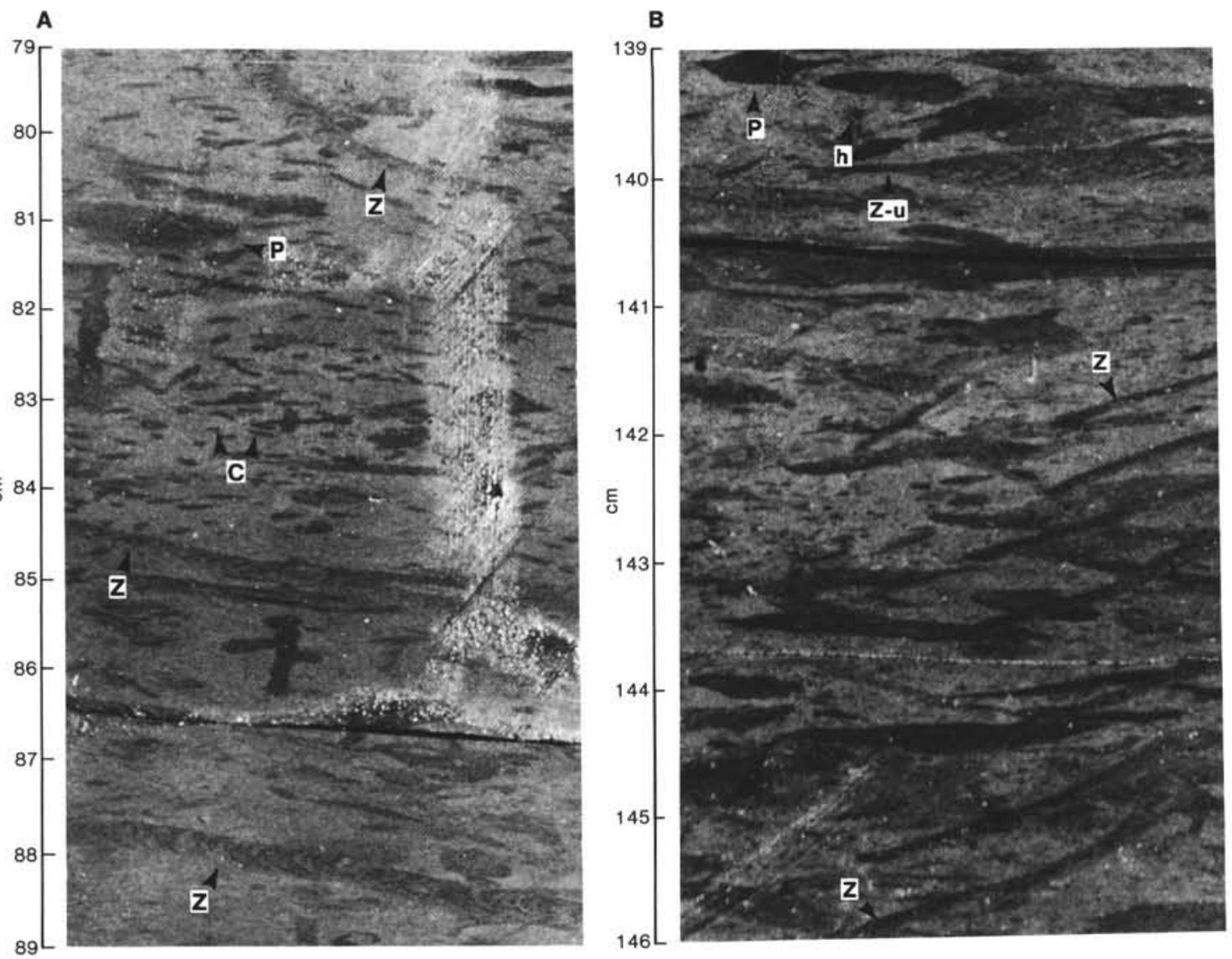

Figure 9. Typical examples of ichnofabric IV. A. Sample 605-52-1, 79-89 cm. B. Sample 605-57-1, 139-146 cm. The ichnofabrics are dominated by burrows, often small sized, belonging to the ichnogenera Chondrites (C), Planolites (P), and Zoophycos $(\mathrm{Z})(\mathrm{Z}-\mathrm{u}=$ Zoophycos with a compressed, formerly open U-shaped marginal tube). In B, between the lower $\mathrm{Z}$ and that above are several whorls of Zoophycos; $\mathrm{h}$ indicates a halo around a ?Planolites burrow. Note that the halo destroys the coloring of the next Planolites (marked with P).

The ichnofauna assemblage indicates moderately oxygen poor conditions within the sediment and somewhat lower burial rates of organic matter.

The assemblage in this unit appears to be more variable than those in the other units, probably because sediments in Core 66 and in the interval from 605-68-4, 30 $\mathrm{cm}$ to $605-69-5,32 \mathrm{~cm}$ are displaced. This movement is characterized by sheared and deformed burrows (Fig. 11). The trace fossil assemblage in the displaced material suggests an origin below the shelf edge. In these sediments the proportion of Zoophycos is higher than in the surrounding deposits.

\section{CONCLUSIONS}

1. The Site 605 sediments recovered off New Jersey belong to the Zoophycos ichnofacies (Seilacher, 1967) as determined by the trace fossil assemblage: Chondrites, Planolites, Thalassinoides, Trichichnus, and Zoophycos commonly occur, whereas Cylindrichnus, Teichichnus, and Skolithos are less frequent. The Zoophycos ichnofacies is characterized by the following environmental conditions:

a. Sediments were deposited below the storm wave base and above the depth of frequently occurring turbidites (Seilacher, 1967). b. The bioturbated zone is often some decimeters to about one meter thick because nutrients are also available deeper within the sediment, for instance, in continental slope deposits. Furthermore, anoxic conditions are often found deeper within such deposits.

c. The distribution of nutrients and the availability of oxygen lead to fractionation of the bioturbated zone into several tiers.

2. The ichnofabric varies considerably throughout the drilled section, allowing subdivision into four ichnofabric units which roughly correspond to the defined lithologic units. In general, the sedimentation rate and availability of nutrients within the deposits are clearly higher in the upper Eocene Unit II than in the older units.

3. The trace fossil assemblage also varies within several decimeters, indicating short-term cyclic fluctuations in environmental conditions. Cycles can be seen in the biogenic structures, depending on the general bioturbational pattern in each unit.

4. Short-term cycles seem to be related to fluctuations in the availability of nutrients within the sediments and oxygen content in the (interstitial ?) respiration water and are visible even where the sediments seem to be lithologically homogeneous. 
A

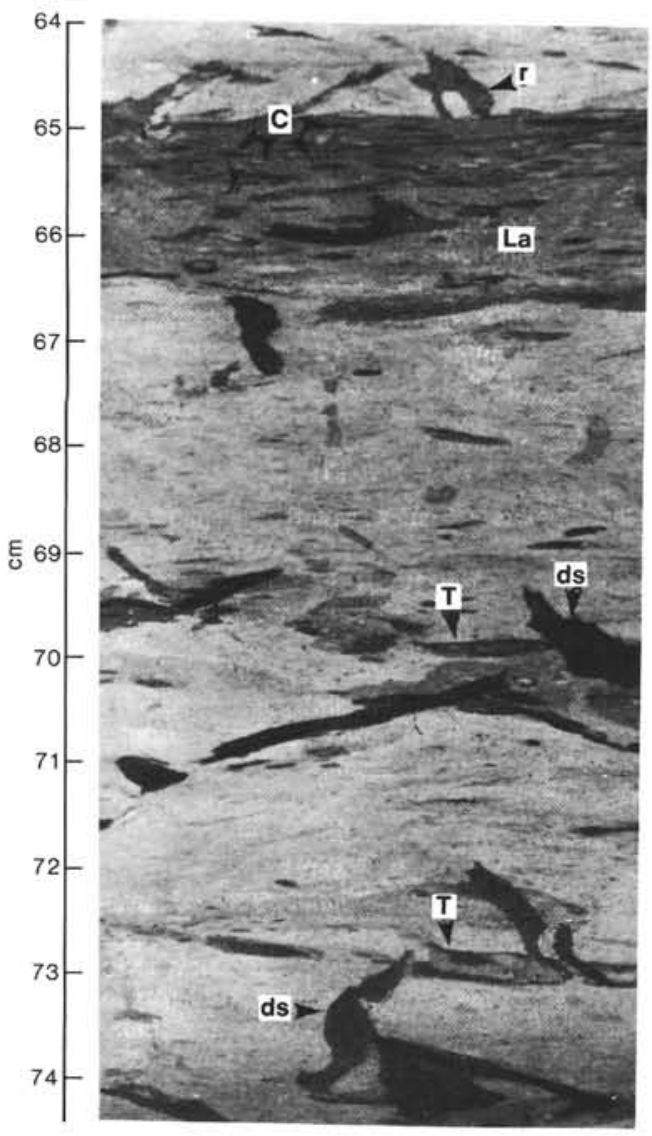

B

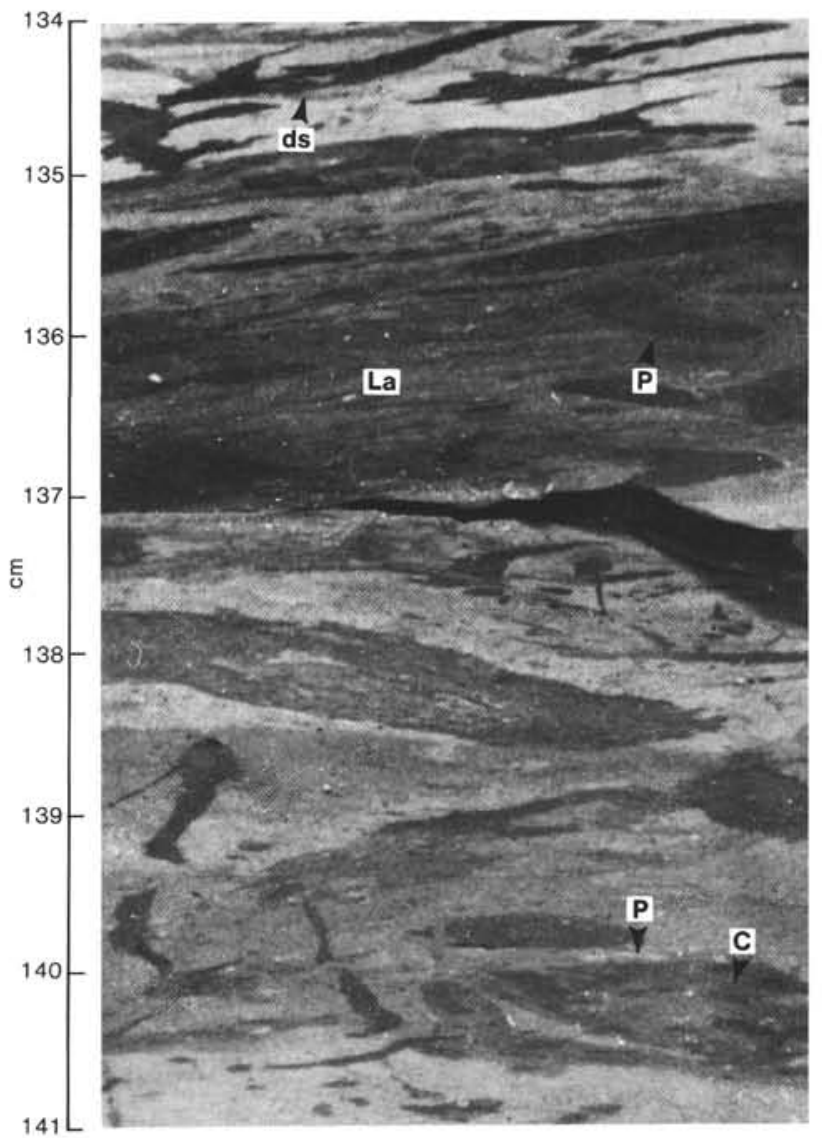

Figure 10. Typical examples of the transition between ichnofabric Units IV and V. A. Sample 605-63-1, 64-74.5 cm. B. Sample 605-63-3, 134-141 cm. Typically in this lower part of the transition the ichnofaunal elements of Unit $\mathrm{V}$ are more frequent. The average size of burrows is somewhat larger than in Unit IV. In A, diagenetic staining is present, and the incomplete coloring leads to hardly recognizable biogenic structures. La documents the beginning of pressure solution, resulting in compression and masking of burrows $(\mathrm{r}$ in $\mathrm{A}$ ). $\mathrm{C}=$ Chondrites, ds = diagenetic staining, $\mathrm{P}=$ Planolites (note different compaction in $\mathrm{A}$ and $\mathrm{B}), \mathrm{T}=$ Thalassinoides (stained and compressed).

\section{ACKNOWLEDGMENTS}

U. von Rad (Hannover) suggested the investigation of the Site 605 biogenic sedimentary structures. H. Beiersdorf (Hannover) provided travel funds from the Deutsche Forschungsgemeinschaft to study the sediments in the DSDP Eastern Core Repository at Lamont-Doherty Geological Observatory (New York). A. A. Ekdale (Salt Lake City) carefully reviewed the manuscript and made helpful suggestions. L. Hobert (Tübingen) improved the English text. All these contributions are gratefully acknowledged.

\section{REFERENCES}

Bromley, R. G., 1981. Enhancement of visibility of structures in marly chalk: modification of the Bushinsky oil technique. Bull. Geol. Soc. Denmark, 29:111-118.

Chamberlain, C. K., 1975. Trace fossils in DSDP cores of the Pacific. J. Paleontol., 49:1074-1096.

Crimes, T. P., 1975. The stratigraphical significance of trace fossils. In Frey, R. W. (Ed.), The Study of Trace Fossils: New York (Springer), pp. 109-130.

Einsele, G., and Mosebach, R., 1955. Zur Petrographie, Fossilerhaltung und Entstehung der Gesteine des Posidonienschiefers im Schwäbischen Jura. N. Jb. Geol. Paläont., Abh., 101:319-430.

Ekdale, A. A., 1977. Abyssal trace fossils in the worldwide Deep Sea Drilling Project cores. In Crimes, T. P., and Harper, J. C. (Eds.), Trace Fossils II. Geol. J., Spec. Issue, 9: Liverpool (Seel House Press), 163-182.
Ekdale, A. A., Muller, L. N., and Novak, M. T., 1984. Quantitative ichnology of modern pelagic deposits in the abyssal Atlantic. Palaeogeogr., Palaeoclimatol., Palaeoecol., 45:189-223.

Frey, R. W., 1970. Trace Fossils of the Fort Hays Limestone Member of the Niobara Chalk (Upper Cretaceous) of West Central Kansas. Univ. Kansas Paleontol. Contrib., Art. 53.

Häntzschel, W., 1965. Vestigia Invertebratorum et Problematica; Fossilium Catalogus I: Animalia pars 108: S'Gravenhage (W. Junk). 1975. Trace fossils and problematica. In Teichert, C. (Ed.), Treatise on Invertebrate Paleontology; Part W, Miscellanea, Suppl. I: New York and Lawrence (Geol. Soc. Am. and Univ. Kansas Press).

Marintsch, E. J., and Finks, R. M., 1978. Zoophycos size may indicate environmental gradients. Lethaia, 11:273-279.

Müller, P. J., and Suess, E., 1979. Productivity, sedimentation rate and sedimentary organic matter in the oceans. I. Organic carbon preservation. Deep-Sea Res., 26:1347-1362.

Pemberton, S. G., and Frey, R. W., 1982. Trace fossil nomenclature and the Planolites-Paleophycos dilemma. J. Paleontol. 56:843-881.

Risk, M. J., and Szczuczko, R. B., 1977. A method for staining trace fossils. J. Sed. Petrol., 48:855-859.

Seilacher, A., 1967. Bathymetry of trace fossils. Mar. Geol., 5:413-428.

Werner, F., and Wetzel, A., 1982. Interpretation of biogenic structures in oceanic sediments. Bull. Inst. Geol. Bassin d'Aquitaine, 31:275288.

Wetzel, A., 1979. Bioturbation in spätquartären Tiefwasser-Sedimenten vor NW-Afrika [Ph. D. dissert.]. Kiel University. 
, 1981. Ökologische und stratigraphische Bedeutung biogener Gefüge in quartären Sedimenten am NW-afrikanischen Kontinentalrand. "Meteor" Forsch.-Ergebnisse, C, No. 34:1-47.

1983a. Biogenic sedimentary structures in a modern upwelling region: northwest African continental margin. In Thiede, J., and Suess, E. (Eds.), Coastal Upwelling and Its Sediment Record, Part B; Sedimentary Records of Ancient Coastal Upwelling: New York (Plenum), pp. 123-144.

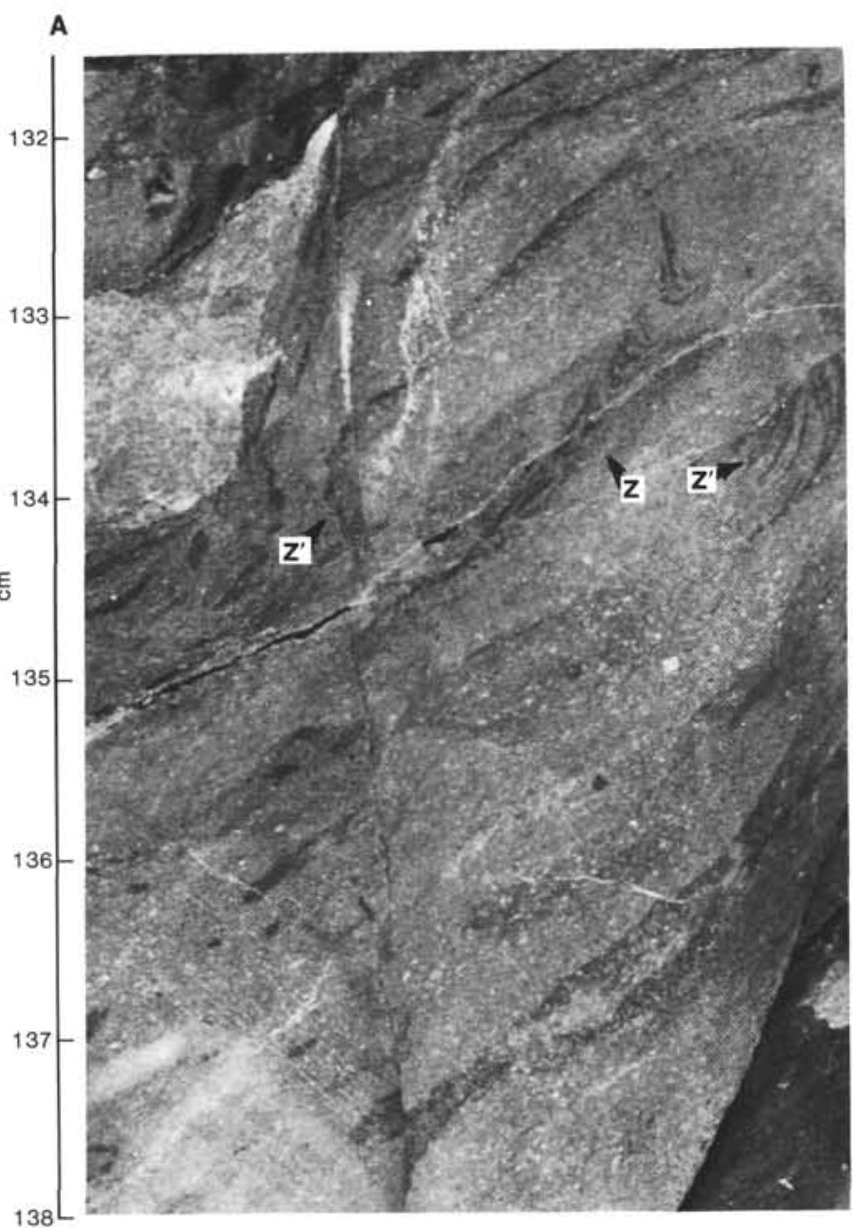

1983b. Biogenic structures in modern slope to deep-sea sediments in the Sulu Sea Basin (Philippines). Palaeogeogr., Palaeoclimatol., Palaeoecol., 42:285-304.

Wetzel, A., and Werner, F., 1981. Morphology and ecological significance of Zoophycos in deep-sea sediments off NW Africa. Palaeogeogr., Palaeoclimatol., Palaeoecol., 32:185-212.

\section{Date of Initial Receipt: 6 February 1985}

Date of Acceptance: 23 December 1985

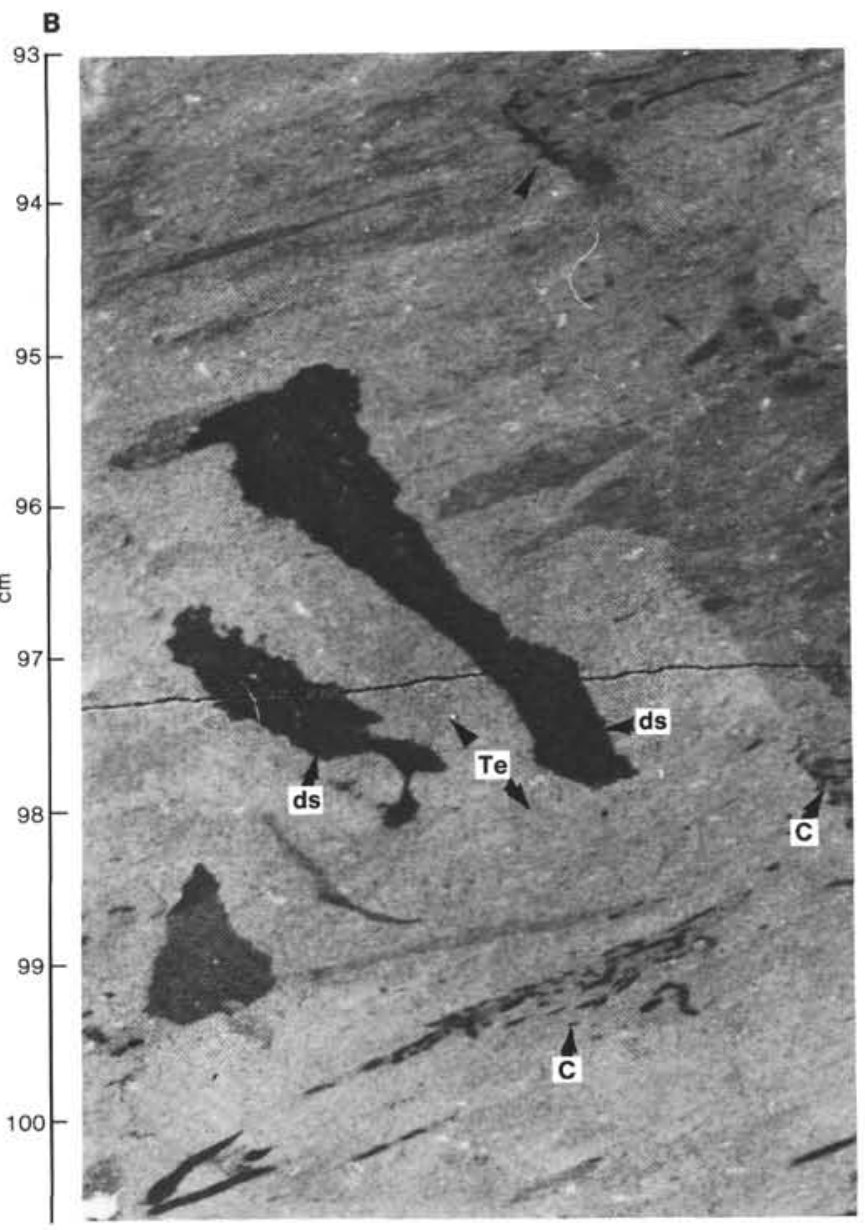

Figure 11. Displaced sediments in ichnofabric Unit V. A. Sample 605-66-3, 131.5-138 cm. Z = normal and Z' $=$ sheared Zoophycos. B. Sample 605-68-6, 93-100.8 cm. Inclined burrows of Chondrites (C), diagenetic staining (ds) of sediment surrounding Teichichnus (Te). Note upward convex lamellae marginally incised in ds lining. 